\title{
Media Consumption Patterns to Get English Learning Information in Tiktok
}

\author{
Herma Retno Prabayanti ${ }^{1 *}$, Yahya Romadoni² ${ }^{2}$ Yanuarita \\ Kusuma $^{3}$
}

\author{
${ }^{1}$ Doctoral Student, Education Management, Universitas Negeri Surabaya \\ ${ }^{2}$ Independent researcher \\ ${ }^{3}$ Communication Science, Faculty of Economics and Communication Bina Nusantara University \\ *Corresponding author. Email: hermaprabayanti@unesa.ac.id
}

\begin{abstract}
Social media has a significant role in the life of an individual, because it can create two-way or more interaction and communication in different places. The social media that are often used and also follow the development of trends in social media applications. TikTok is one of the most popular social media applications in Indonesia. The factor of the COVID-19 pandemic outbreak that spreads throughout the world makes distance learning still implemented in Indonesia until 2021. Students can study not only from formal schools, but also from social media networks. TikTok is here to answer the needs of these students in the era of the COVID-19 pandemic. Educational content creators take advantage of this facility to create more interesting and educational videos for Generation Z to watch. Based on the TikTok Data Report in 2019, videos with the topic of language education ranked second in the Top 5 most popular knowledge category. Based on these facts, language learning plays an important role in the distribution of educational videos on TikTok. By using correlational quantitative methods, researchers can find out the relationship between consumption patterns of high school students in Surabaya. It is known that there is a positive relationship between high school students' TikTok media consumption patterns that lead to motivation to learn. This means that it can be input for other educational fields who want to use Tiktok as a learning medium in order to improve the quality of video content uploaded later.
\end{abstract}

\section{Keywords: TikTok, Media Consumption Patterns, Generation Z, Learning methods}

\section{INTRODUCTION}

The rapid development of information and communication technology in the 21 st century has contributed to the progress of various fields, one of which is communication. The more advanced development of devices to access information through mobile devices such as smartphones makes communication faster and easier. This is also the influence of easily accessible social media applications. According to Ratri (2018:20), everything that leads to internet and mobile-based services that facilitate users to join an online conversation is called social media. A number of social media applications are available in digital app stores, namely the App Store on iOS and the Play Store on Android. The availability of a number of social media applications on smartphones provides easy access for everyone to interact, especially the student segment as part of Generation Z.
Generation $\mathrm{Z}$ is the generation born from 1995 to 2010 according to The Generation Guide on fourhooks.com. They are the generation that was born when information technology was integrated with the digital era. This is what makes Generation $\mathrm{Z}$ can be considered as true digital natives (Haydan, 2021). Generation $\mathrm{Z}$ has special characteristics to respond to information technology. They are more technologically savvy than the previous generation, and love to communicate with all walks of life. It is also mentioned that Generation $\mathrm{Z}$ is more independent and careful to maintain privacy. Generation $Z$ tends to be more private, after learning what the previous generation did not do. The next character,

Generation Z, is more tolerant to be able to accept all the differences. They easily accept all differences with an open- minded attitude even though they are in a different environment with them. This generation is also full of ambition to achieve success in their careers. 
Social media is a part of Generation $\mathrm{Z}$ culture, according to Jayme (quoted in Kalia, 2013). Social media also has a significant role in the life of an individual, because it can create two-way interaction and communication or more in different places. The social media that are often used include: WhatsApp Messenger, Telegram, LINE, Discord, TikTok, Instagram, Twitter, and Facebook. Along with the times, they also follow the development of trends in social media applications that are used. TikTok is one of the most popular social media applications in Indonesia.

The social media application TikTok is one of the popular media for sharing short videos from handheld devices. TikTok introduces a number of features and special effects that can be used to make video content more interesting. TikTok application users can add certain texts, animations, transitions, special filters, this is a generation $\mathrm{Z}$ stimulus to increase creativity and freedom of expression through these short videos. They can not only seek entertainment alone, but also can learn about various fields of study. The TikTok application itself has been ranked as the first most downloaded in the App Store on iPhone and on the Google Play Store on Android since early 2021. Then, based on data quoted from Key Market Indicators (KMI) (Dagendart, 2021) the number of TikTok application users in Indonesia has increased significantly from year to year. By 2025, the number of TikTok users in Indonesia is predicted to reach 4.2 million users. This indicates that TikTok already has a strategic position as a social media application, especially Generation $\mathrm{Z}$ among students.

There are four main goals of social media applications: entertainment, socialization, information, and academics (Yang, 2020). Everyone who plays a role in the world of education can use social media as a teaching media tool. (Belardi, 2013) states that an effective learning process with the use of appropriate technology can guarantee student success in the classroom. Educators can consider the use of social media as a learning medium.

In the COVID-19 pandemic, all educators are implementing distance learning (PJJ) at all levels. There are various feedback from educators, students, and parents. Reporting from cnnindonesia.com, a total of 69 STAN students were subject to drop out after the implementation of distance learning (PJJ). One of the expelled students stated that the PJJ process complicates learning. Contrary to research by Prawiyogi et al regarding the effectiveness of distance learning on student learning at SDIT Cendekia Purwakarta. They stated that PJJ is quite effective to do. This can be seen from the opinions of students who support and assess that PJJ is effectively implemented. The same thing was also stated by Alkhuzaefi (2020) about the effectiveness of learning for students at SDN 02 Cibarusah Kota through online methods. The results of his research show that distance learning implemented at the school is quite effective to implement. The average student answered quite comfortably and effectively even though there were several problems involving the surrounding environment. To increase the effectiveness of PJJ, Alkhuzaefi (2020) stated that one of them is that it is necessary to provide concise learning materials by minimizing sending material in the form of large videos. Then, the selection and use of language that is easy to understand when delivering the material in the video.

The factor of the COVID-19 pandemic outbreak that spreads throughout the world makes distance learning still implemented in Indonesia until 2021. Certain innovations should be considered so that online learning is more interactive and does not reduce students' motivation to absorb subject matter. They can study not only from formal schools, but also from social media networks. TikTok is here to answer the needs of these students in the era of the COVID19 pandemic. Educational content creators take advantage of this facility to create more interesting and educational videos for Generation $\mathrm{Z}$ to watch.

Based on the TikTok Data Report in 2019, videos with the topic of language education ranked second in the Top 5 most popular knowledge category. Based on these facts, language learning plays an important role in the distribution of educational videos on TikTok. One of them is learning English. A number of educational accounts on TikTok are here to present materials on learning English. They pack educational video content with special effects and interesting editing. However, there has been no research that touches more deeply on students' construction of English learning videos. Based on the description above, the researchers are interested in further researching how the relationship between students' consumption patterns to get information on learning English in TikTok media. By knowing the consumption patterns of students, the character of the video that should be uploaded to tiktok will be known This means that it can be input for other educational fields who want to use tiktok as a learning medium in order to improve the quality of video content uploaded later.

In this study, there is a statistical hypothesis that consists of two tentative predictions of the result. There are alternate hypothesis and null hypothesis. The hypotheses are formulated like this:

1. The alternate hypothesis $(\mathrm{Ha})$

There is a large correlation between consumption pattern of students and English learning information.

2. The null hypothesis (Ho)

There is a small correlation between 
consumption pattern of students and English learning information.

\section{THEORETICAL REVIEW}

\subsection{Uses and Gratification}

This theory sees the media as having limited influence because they are less able to choose and control. People have self-awareness, and they are able to understand and state the reasons they use media. They see the media as a way to satisfy their needs. What do people actually do with the media? This is actually the main focus of the Theory of Use and Gratification. The assumption is; (1) Active audiences and their use of media are goal-oriented, (2) Initiative in linking need satisfaction to certain media choices lies with audience members, (3) Media competes with other sources for need satisfaction, (4) People have sufficient selfawareness of media use, interests and motives. So that it can provide an accurate picture of the usefulness for researchers, (5) Assessment of the value of media content can only be assessed by the audience.

Table 1. Type of needs table

\begin{tabular}{|c|c|c|}
\hline $\begin{array}{l}\text { The Types } \\
\text { of needs }\end{array}$ & Descriptions & Media examples \\
\hline Cognitive & $\begin{array}{l}\text { Getting information, } \\
\text { knowledge, and } \\
\text { understanding }\end{array}$ & $\begin{array}{l}\text { Television and } \\
\text { news }\end{array}$ \\
\hline Affective & Emotional experiences & $\begin{array}{c}\text { Film and movie } \\
\text { show }\end{array}$ \\
\hline $\begin{array}{l}\text { Personal } \\
\text { integrations }\end{array}$ & $\begin{array}{c}\text { Credibility } \\
\text { improvement, } \\
\text { confident, and status }\end{array}$ & $\begin{array}{l}\text { Audio and } \\
\text { visual }\end{array}$ \\
\hline $\begin{array}{c}\text { Social } \\
\text { Integrations }\end{array}$ & $\begin{array}{c}\text { Connection with } \\
\text { society }\end{array}$ & Internet \\
\hline Stress Release & Escape and diversion & $\begin{array}{l}\text { Television, } \\
\text { Film, Video, } \\
\text { Radio }\end{array}$ \\
\hline
\end{tabular}

The classification of needs and audience satisfaction according to McQuail (1972) includes, Diversion is defined as getting out of the routine of everyday problems. Personal relationship (personal relationship) that occurs when people use the media as a substitute for friends. Personal identity is a way to emphasize individual values. Monitoring (surveillance) information about how the media will help individuals achieve something. Based on the needs classification that has been done, it is clear that this theory states that people actively seek certain media and certain content to produce certain satisfaction. This is done to meet the needs of each individual or different media consumers.

\subsection{Generations $Z$}

Generation Z, which is the current productive generation, has different characteristics from the previous generation (millennials). In a study conducted by the Paw Research Center in 2019, researchers did not refer to the newest generation as Generation Z, but still as the Post-Millennial generation. Along with the development of time, the post- millennial generation is increasingly occupying popular culture and other media and journalistic activities (Dimock; 2019).

From the data collected by the Paw Research Center through Google trends in 2019, it is stated that the generation $\mathrm{Z}$ and millennials do not have a clear threshold, because theirbehavior is not too different. For researchers from the Paw Research center for analysis purposes, it was decided that the boundary between generation $\mathrm{Z}$ and millennials was in the year of birth in 1996. This is viewed from political, economic and social aspects. According to Dimock, during the 9/11 terrorist attacks, the millennial generation was aged 5 and still has a historical record related to international political issues, including silver Iran and Afghanistan, so that the millennial generation tends to be more racist than Generation $\mathrm{Z}$. Along with growing technological advances, Generation $\mathrm{Z}$ who was born at that time the digital world has advanced, making unique characteristics very inherent.

Based on the results of the 2020 census released by the Central Statistics Agency (BPS) in 2021, the number of people born in Indonesia from 1997 to 2012 and called Generation $\mathrm{Z}$ is $27.94 \%$ Meanwhile, the number of millennials is still below Generation Z, so now Generzi Z plays an important and very influential role in the growth of various sectors in Indonesia. In the context of education, understanding the characteristics of each generation is very important to determine an effective education strategy (Rahmah, 2021). So the digital learning space is increasingly open and becomes a challenge for the Millennial Generation to be able to make Generation $\mathrm{Z}$ get information in an attractive learning package.

\subsection{Media Consumption Pattern}

The media as a provider of information has always been a public reference. If a decade ago television dominated audio- visual information, in this digital era, digital media has become the center of information seeking. People who always need 
information, every day consume data from various digital media. The development of information and communication technology in the digital world makes people's media consumption patterns change, from television to the internet. Through correlational tests that have been carried out, it shows that age differences affect media selection. The younger the age of the respondents, the more they prefer to use online media than conventional media. One of the public issues that has received the attention of digital media users, especially social media today, is the issue of education. (Lestari, Yulia, Puspita; 2017, $\mathrm{p}: 159)$.

The large number of millennials and generation $\mathrm{Z}$ has led to an increase in the number of digital media consumers. In previous studies, it was found that media engagement is a form of reaction from media consumption. So that media consumption patterns are a combination of cognitive behavior, motivation, habits, and normative behavior where this is consistent with media content and media consumption by people (consumers) in everyday life (Bennett, WL \& Segerberg; 2012, p: 742).

Media consumption behavior is switching from conventional to digital media in the form of social media. One of the most popular social media apps in 2020 is TikTok. Based on Apptopia data quoted from kompas.com, TikTok became the most downloaded application in 2020, with a total of 850 million downloads. Not only that, TikTok also took first place in the Highest Grossing App category, beating Tinder, YouTube, Disney Plus, and other digital apps. As of February 2021, TikTok's daily active users reached 35.28 million users worldwide (Stephanie, 2021).

Online learning makes Generation $\mathrm{Z}$ more creative in getting learning media. With the need for information related to learning media, TikTok has the opportunity to be glimpsed by Generation Z. As in a study that revealed the attractiveness of TikTok in learning English, it was found that TikTok has an attraction because the material is simple and interesting. Learning in the form of videos equipped with backsounds, images, edit filters, and comments between users provides benefits in the form of information. It was found that there are five best types of lessons on TikTok media, namely (1) vocabulary, (2) Pronunciation, (3) Grammar), (4) Common Mistakes), (5) English Facts (Warini, Dewi, Susanto, Dewi; 2020; p.34).

\section{METHODS}

\subsection{Method}

The researcher used a descriptive study which provides symptoms and facts systematically and accurately. This study used a quantitative method, with a questionnaire as the instrument to collect data. In addition, the researcher applied a correlational approach to find weather or not there is a relationship between variables. The researcher intends to detect the extent to which variations in research variables are related to other variations, because they are able to describe the changes studied. In correlational research, the variable used to expect predictor variable, while the predicted variables are criteria variables (Riyanto, 2007: 120). Predictor variable is called as the independent variable and the criterion variable is called as the dependent variable.

The variables used by researchers are variable $\mathrm{X}$ (independent); namely the consumption pattern of students and the variable Y (dependent); namely English learning information. The researcher used descriptive quantitative to attempt collecting quantifiable information for statistical analysis of the population sample. The population in this study were high school students in the City of Surabaya. Based on data from the Central Statistics Agency (Badan Pusat Statistika) in 2019, the number of high school students in the city of Surabaya was 60,706 students.

The researcher only limited the sample to school students in Surabaya. Kompas article (Kasih, 2021) stated that the top 10 high schools in the city of Surabaya based on data from the 2020 Higher Education Entrance Test Institute (Lembaga Tes Masuk Perguruan Tinggi) recorded that the top 10 best school in Surabaya are dominated by public schools. Therefore, the researcher only used a population of high school students in the city of Surabaya as many as 22,417 students. Then, the researcher applied a purposive sampling technique, with a sample of 34 high school students in the city of Surabaya who follow English learning content in TikTok. The criteria for respondents to be used in this study were: 1) State high school students in the city of Surabaya 2) Have a TikTok account 3) Follow at least 1 English Leaning TikTok Account.

Operationalization of the concept in this study: 1) The concept of surveilance, describes a person's habits in collecting the required information from a media. The data generated later is about the experience of respondents applying what they learned from a content, things that are liked and considered interesting from learning content on TikTok 2) The concept of diversion explains how respondents consume media to reliave stress or as a way to escape for entertainment or reduce stress. Through this concept, the data generated will be a matter of taste or content genre, the duration of the content being accessed, the right time to access social media, and the duration of using social media.

There are 2 main indicators used by researchers which are contained in 42 questions. They are the consumption pattern of students and English 
learning information. The consumption patter itself consists of cognitive behavior, motivation, habit, and normative behavior (Bennett, W.L. \& Segerberg; 2012, p:742), whereas the English learning information consists of Vocabulary, Pronunciation, Grammar, Common Mistakes, and English Facts (Warini, Dewi, Susanto, Dewi; 2020; p.34)

\subsection{Analysis}

After obtaining the data, the researcher analyzed it by using Pearson Product-Moment Correlation. It was a parametric test to explore the relationship between 2 variables. It was used because the data was normally distributed. It computed by using IBM SPSS for Windows release 24.

The stages were as follows:

- Assessing validity test of instrument by Pearson Product Moment

- Assessing reliability test of instrument by Alpha Cronbach

- Assessing normality test of instrument by Kolmogorov-Smirnov

- Assessing homogeneity test of instrument by ANOVA test

- Assessing linearity test of instrument

- Computing correlation number by using Pearson Product Moment

For responding to the research question, the researcher interpreted the numerical data obtained by looking the results of correlation number of Pearson Product Moment test based on Cohen (1988: 79-81)

- If the $r$ value is more than .5 , it means there is a large correlation between consumption pattern of students and English learning information.

- If the $r$ value is less than .3 , it means there is a small correlation between consumption pattern of students and English learning information.

First, the researcher assessed a validity test of instrument. Validity measures what should the measurement look like based on some particular considerations. It is used to know what are things that have to be put and measured in a questionnaire. The researcher used Pearson Product moment to measure the validity of the test by comparing between Sig. (2- tailed) value and the probability value (p). Based on Pallant (2010:135), instrument validation can be measured by assessing the significance level:

1. If the probability value (p) is less than .05 and has positive value, it means the item of questionnaire is valid.
2. If the probability value (p) is less than .05 and and has negative value, it means the item of questionnaire is invalid.

3. If the probability value (p) is more than .05 , it means the item of questionnaire is invalid.

Second, the researcher assessed reliability test of instrument. The researcher used Cronbach Alpha to measure the reliability of the test by comparing between Sig. (2-tailed) value and the probability value (p). According to V. Wiratna Sujarweni (2014:193), instrument reliability can be measured by assessing Cronbach Alpha value:

1. If the Cronbach Alpha value is more than .60, it means the item of questionnaire is reliable.

2. If the Cronbach Alpha value is less than .60, it means the item of questionnaire is not reliable.

Based on the analysis, all items are more than .60. Therefore all items in the questionnaire are reliable.

Third, the researcher assessed a normality test of instrument. To measure the data in questionnaire is distributed normally. The researcher used Pearson Product moment to measure the validity of the test by comparing between Sig. (2- tailed) value and the probability value (p). Based on Pallant (2010:135), it can be measured by assessing the significance level:

1. If the probability value (p) is more than .05 , it means the data is normally distributed.

2. If the probability value (p) is less than .05 , it means the data is not normally distributed.

Here the analysis:

Table 2. One-Sample Kolmogorov-Smirnov Test Unstandardize

d Residual

\begin{tabular}{|c|c|c|}
\hline \multicolumn{2}{|l|}{$\mathrm{N}$} & 34 \\
\hline \multirow{2}{*}{$\begin{array}{l}\text { Normal } \\
\text { Parameters } \\
\text { a,b }\end{array}$} & Mean & .0000000 \\
\hline & Std. Deviation & 6.76736490 \\
\hline \multirow{3}{*}{$\begin{array}{l}\text { Most } \\
\text { Extreme } \\
\text { Differences }\end{array}$} & Absolute & .075 \\
\hline & Positive & .075 \\
\hline & Negative & -.060 \\
\hline \multicolumn{2}{|c|}{$\begin{array}{c}\text { Test } \\
\text { Statistic } \\
\end{array}$} & .075 \\
\hline \multicolumn{2}{|c|}{ Asymp. Sig. (2-tailed) } & .200 \\
\hline
\end{tabular}


Furthermore, based on the analysis, the Sig. (2-tailed) value is .200 which is more than .05 . It means the data is distributed normally in the questionnaire showed.

Fourth, the researcher assessed a homogeneity test of instrument. Parametric techniques in this section make the assumption that samples are obtained from populations of equal variances. This means that the variability of scores for each of the groups is similar. To test this, SPSS performs Levene's test for equality of variances.

Based on Pallant (2010:207), it can be measured by assessing the significance level: If the probability value $(p)$ is more than .05 , it means the data is homogeny.

1. If the probability value (p) is less than .05 , it means the data is not homogeny.

Here the analysis:

Table 3. Test of Homogeneity of Variances

\begin{tabular}{cccc}
\hline Levene Statistic & df1 & df2 & Sig. \\
\hline 1.778 & 1 & 66 & .187
\end{tabular}

According homogeneity of variances test (see table 3), it can be known that the significance level is .939. It is more than .05 which means the data is homogeny. Therefore, the researcher is able to continue to next stages.

Fifth, the researcher assessed linearity test of instrument. The researcher used linearity test to know is there any linear relation between independent variable and dependent variable. It can be measured by assessing the significance level:

1. If the Deviation from Linearity significant value is more than .05 , it means there is a significant linear correlation between independent variable and dependent variable.

2. If the Deviation from Linearity significant value is below .05, it means there is no significant linear correlation between independent variable and dependent variable.

Based on the analysis ANOVA table, the deviation from Linearity Sig. value is known that is .187 which is more than

.05. It means there is a significant linear relation between independent variable and dependent variable.

\section{RESULTS AND DISCUSSION}

\subsection{Correlation between consumption pattern of students and English learning information}

To measure the correlation, the researcher calculated the correlation number by using Pearson Product Moment. Here the analysis:

Table 4. Correlations

\begin{tabular}{|c|c|c|c|}
\hline & & $\begin{array}{l}\text { Consumption } \\
\text { Pattern of } \\
\text { Students }\end{array}$ & $\begin{array}{l}\text { English } \\
\text { Learning } \\
\text { Information }\end{array}$ \\
\hline \multirow{4}{*}{$\begin{array}{l}\text { Consumption } \\
\text { Pattern of } \\
\text { Students }\end{array}$} & Pearson & 1 & .777 \\
\hline & Correlation & & \\
\hline & $\begin{array}{l}\text { Sig. (2- } \\
\text { tailed) }\end{array}$ & & .000 \\
\hline & $\mathrm{N}$ & 34 & 34 \\
\hline \multirow{4}{*}{$\begin{array}{l}\text { English } \\
\text {-Learning } \\
\text { Information }\end{array}$} & Pearson & .777 & 1 \\
\hline & Correlation & & \\
\hline & $\begin{array}{l}\text { Sig. (2- } \\
\text { tailed) }\end{array}$ & .000 & \\
\hline & $\mathrm{N}$ & 34 & 34 \\
\hline
\end{tabular}

\subsection{Discussion}

Based on analysis data, such as: validity test, reliability test, normality test, homogeneity test, linearity test, and correlation test, the researcher found the results as follows.

As stated in introduction, there is two predictions of the results in this study. First it alternate hypothesis, and the other is a null hypothesis. The alternate hypothesis $(\mathrm{Ha})$ explains that there is a large correlation between consumption pattern of students and English learning information. Whereas the null hypothesis (Ho) states that the reis a small correlation between consumption pattern of students and English learning information. As a median to test the hypothesis, the researcher used Pearson Product-Moment test to get the results of the data gained.

According to the data of questionnaire presented before, it showed that there is a large correlation between consumption pattern of students and English learning information. Thus, it can be concluded that the null hypothesis is rejected and the alternate hypothesis is accepted.

The large correlation between consumption pattern of students and English learning information confirmed that senior high school students had a good competence in English learning through TikTok. In addition, the alternate hypothesis of this research supported the previous study 


\section{ACKNOWLEDGMENT}

We thank God, parents, the participants who assist in completing the questionnaire, Crew of Kece Media by UNESA who give an insight and inspiration to choose TikTok as media to be studied, friends, colleague, and all people who indirectly help this study

\section{REFERENCES}

[1] West, R. Turner, H.L. (2008). “ Teori Komunikasi, Analisis dan Aplikasi”. Salemba Humanika, Jakarta J. Clerk Maxwell, A Treatise on Electricity and Magnetism, 3rd ed., vol. 2. Oxford: Clarendon, 1892, pp.68-73.

[2] Aslichati L, Prasetyo B, Irawan P. 2010. Metode Penelitian Sosial. Universitas Terbuka: Jakarta.

[3] Pallant, J. (2010). SPSS Survival Manual - A step by step guide to data analysis using SPPS (4th Edition). Berkshire: Open University Press.

[4] Riyanto,Y. Oktarianda,T.A. (2007). Metodologi Penelitian Kualitatif dan Kuantitatif, Unesa University Press

[5] Lestari.,Y.,Yulia,V.,Puspita,Y. (2017). Jurnal Penelitian Komunikasi, Vol. 20 No. 2, 149-160: ISSN: 1410-8291 | e-ISSN: 2460-0172 | http://bppkibandung.id/index.php/jpk

[6] Bennett, W.L. \& Segerberg, A. (2012) THE LOGIC OF CONNECTIVE ACTION. Information, Communication \& Society. [Online] 15 (5), 739-768. Available from: doi:10.1080/1369118X.2012.670661.

[7] Warini, N.L., Dewi, N.P.E.S., Susanto, P.C., Dewi, P.C. (2020) Daya Tarik TikTok Sebagai Media Pembelajaran Bahasa Inggris Online, Sintesa Prosiding 2020, 27-33. ISBN: 978-60253420-6-6

[8] Dimock,M, (2019) Defining generations: Where Millennials and Generation $\mathrm{Z}$ begins. Accessed from Pew Research, https://www.pewresearch.org/facttank/2019/01/17/where-millennials- end-andgeneration-z-begins/Stephanie,C. (2021, April 19). Jumlah Pengguna Aktif Bulanan TikTok Terungkap. Kompas online. Accessed from https://tekno.kompas.com/read/2021/04/19/1402 0037/jumlah-pengguna- aktif-bulanan-tiktokterungkap?page=all.

[9] Rahmah, D.N, (2021) Gen Z Dominan, Apa Maknanya bagi Pendidikan Kita?, Pusat Penelitian Kebijakan. Accessed from https://puslitjakdikbud.kemdikbud.go.id/produk/ artikel/detail/3133/gen- z-dominan-apamaknanya-bagi-pendidikan-kita

[10] Dagenhard,J. (2021, Juli). TikTok Users in Indonesia 2017-2025. Statistika.com Accessed from

https://www.statista.com/forecasts/1142675/tik tok-users-in-indonesia

[11] Haydan,R. (2021,Februari) Ini Perbedaarn Antara Milenial dan Gen Z Saat Menggunakan Sosial Media. Bisnis.com Accessed from https://lifestyle.bisnis.com/read/20210210/220/ 1354914/ini-perbedaan- antara-milenial-dangen-z-saat-menggunakan-sosial-media 